\title{
NOTES
}

\section{Amidepsine E, an Inhibitor of Diacylglycerol Acyltransferase Produced by Humicola sp. FO-5969}

\author{
Hiroshi Tomoda, Yuichi Yamaguchi, Noriko Tabata, \\ Tatsuya Kobayashi, RoKuro Masuma, \\ Haruo Tanaka and Satosht ŌMURA* \\ Research Center for Biological Function, \\ The Kitasato Institute, and \\ School of Pharmaceutical Sciences, Kitasato University, \\ Minato-ku, Tokyo 108, Japan
}

(Received for publication March 18, 1996)

As we reported previously ${ }^{1,2)}$, amidepsines $\mathrm{A}$ to $\mathrm{D}$ were isolated from the culture broth of Humicola sp. FO-2942 as inhibitors of diacylglycerol acyltransferase ${ }^{3)}$ (acylCoA: 1,2-diacyl-sn-glycerol $O$-acyltransferase, abbreviated as DGAT) [EC 2.3.1.20]. In the course of our continuous screening, a fungal strain FO-5969 was found to produce different members of amidepsines. Amidepsine $\mathrm{A}$ and a new compound named amidepsine E (Fig. 1), were isolated from the culture broth of the strain. Amidepsine E was not detected in the FO-2942 culture broth prepared under the reported condition ${ }^{11}$. In this paper, the taxonomy of the producing strain, fermentation, isolation, biological properties and structure elucidation of amidepsine $\mathrm{E}$ are described.

The strain FO-5969 was isolated from a soil sample collected at Asaka, Saitama, Japan. On potato-dextrose agar, corn meal agar, malt extract agar and yeast extractsoluble starch (YpSs) agar, this strain grew rapidly to form white to gray colonies with diameters of $60 \sim 90$ $\mathrm{mm}$ after incubation for 14 days at $25^{\circ} \mathrm{C}$. At $37^{\circ} \mathrm{C}$, growth is nil. Conidia, abundantly born on the colony surface, were solitary, and were produced directly on the vegetative hyphae or on short branches (Fig. 2). They were smooth, dark brown, unicellular, thin-walled, globose to subglobose, and $10 \sim 16 \mu \mathrm{m}$ in size. The above characteristics indicated that the strain FO-5969 belongs to the genus Humicola ${ }^{4}$.

A slant culture of the strain FO-5969 grown on YpSs agar was used to inoculate a $50-\mathrm{ml}$ test tube containing $10 \mathrm{ml}$ of the seed medium (glucose $2.0 \%$, yeast extract $0.2 \%, \mathrm{MgSO}_{4} \cdot 7 \mathrm{H}_{2} \mathrm{O} 0.05 \%$, Polypepton $0.5 \%, \mathrm{KH}_{2} \mathrm{PO}_{4}$ $0.1 \%$ and agar $0.1 \%, \mathrm{pH} 6.0$ ). The test tube was shaken on a reciprocal shaker for 3 days at $27^{\circ} \mathrm{C}$. One $\mathrm{ml}$ of the seed culture was transferred into $100 \mathrm{ml}$ of the production medium (sucrose $2.0 \%$, glucose $1.0 \%$, corn steep liquor $1.0 \%$, meat extract $0.5 \%, \mathrm{KH}_{2} \mathrm{PO}_{4} 0.1 \%$, $\mathrm{MgSO}_{4} \cdot 7 \mathrm{H}_{2} \mathrm{O} 0.05 \%$, trace elements containing in g/liter: $\mathrm{FeSO}_{4} \cdot 7 \mathrm{H}_{2} \mathrm{O} 1.0, \mathrm{MnCl}_{2} \cdot 4 \mathrm{H}_{2} \mathrm{O} 1.0, \mathrm{ZnSO}_{4}$. $7 \mathrm{H}_{2} \mathrm{O} 1.0, \mathrm{CuSO}_{4} \cdot 5 \mathrm{H}_{2} \mathrm{O} 1.0$ and $\mathrm{CoCl}_{2} \cdot 2 \mathrm{H}_{2} \mathrm{O} 1.0$ ( $1 \mathrm{ml}), \mathrm{CaCO}_{3} 0.3 \%$ and agar $0.1 \%, \mathrm{pH} 6.0$ ) in a $500-\mathrm{ml}$ Erlenmeyer flask. The fermentation was carried out at $27^{\circ} \mathrm{C}$ under a stationary condition.

To the 13-day old whole broth (1.6 liters) was added $1500 \mathrm{ml}$ of acetone. After the acetone extracts were filtered and concentrated, the resulting aqueous solution was extracted with $1500 \mathrm{ml}$ of ethyl acetate. The extracts were dried over $\mathrm{Na}_{2} \mathrm{SO}_{4}$ and concentrated in vacuo to dryness to yield a brownish oil $(570 \mathrm{mg})$. The material suspended in $30 \%$ aq acetonitrile, was subjected to an octadecyl silyl (ODS) column (Senshu SSC-ODS-7515$12,30 \mathrm{~g}$ ). The materials were eluted stepwise with $\mathrm{CH}_{3} \mathrm{CN}-0.05 \% \quad \mathrm{H}_{3} \mathrm{PO}_{4}$ solutions $(300 \mathrm{ml}$ each, $3: 7$, $5: 5,7: 3$ and $10: 0, v / v)$, and each $30 \mathrm{ml}$ of the eluate was collected. The 18 th $\sim 19$ th fractions were combined, concentrated and extracted with ethyl acetate to give after evaporation a yellowish powder $(28.0 \mathrm{mg})$. The resulting active powder was purified by preparative HPLC (YMC-pack D-ODS-5, $20 \times 250 \mathrm{~mm} ; 50 \% \mathrm{CH}_{3} \mathrm{CN}$ in $0.05 \% \mathrm{H}_{3} \mathrm{PO}_{4} ; \mathrm{UV}$ at $210 \mathrm{~nm} ; 8.0 \mathrm{ml} /$ minute). Under these conditions, amidepsines $\mathrm{A}$ and $\mathrm{E}$ were eluted as a peak with retention times of 54.0 and 57.0 minutes, respectively, each of which was concentrated and extracted with ethyl acetate to give pure amidepsine A $(6.7 \mathrm{mg})$ as a pale yellow powder and impure amidepsine E $(3.0 \mathrm{mg})$. Amidepsine $\mathrm{E}$ was finally purified by preparative HPLC (YMC-pack D-ODS-5, $20 \times 250 \mathrm{~mm}$; $45 \% \mathrm{CH}_{3} \mathrm{CN}$ in $0.05 \% \mathrm{H}_{3} \mathrm{PO}_{4} ; \mathrm{UV}$ at $210 \mathrm{~nm} ; 9.0$ $\mathrm{ml} /$ minute). It was eluted with a retention time of 62.0 minutes to give pure amidepsine $\mathrm{E}(2.9 \mathrm{mg})$ as a pale yellow powder.
Fig. 1. Structures of amidepsines A and E.<smiles>COc1cc(C)c(C(=O)Oc2cc(C)c(C(=O)Oc3cc(C)c(C(=O)N[C@@H](C)C(=O)O)c(O)c3)c(O)c2)c(OC)c1</smiles>

Fig. 2. Photomicrograph of conidia of strain FO-5969. Bar represents $20 \mu \mathrm{m}$.

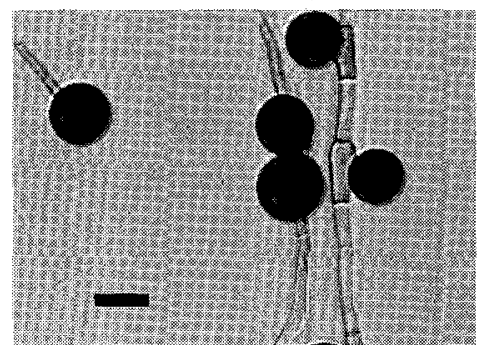


Table 1. Physico-chemical properties of amidepsine E.

\begin{tabular}{|c|c|}
\hline Appearance & Pale yellow powder \\
\hline Molecular weight & 581 \\
\hline Molecular formula & $\mathrm{C}_{30} \mathrm{H}_{31} \mathrm{O}_{11} \mathrm{~N}$ \\
\hline \multicolumn{2}{|l|}{ FAB-MS $(m / z)$} \\
\hline Positive & $\begin{array}{l}582[\mathrm{M}+\mathrm{H}]^{+} \\
604[\mathrm{M}+\mathrm{Na}]^{+}\end{array}$ \\
\hline Negative & $580[\mathrm{M}-\mathrm{H}]^{-}$ \\
\hline \multicolumn{2}{|l|}{ HRFAB-MS $(m / z)$} \\
\hline Calcd: & $582.1975\left(\right.$ for $\left.\mathrm{C}_{30} \mathrm{H}_{32} \mathrm{O}_{11} \mathrm{~N}\right)$ \\
\hline Found: & 582.1977 \\
\hline$[\alpha]_{\mathrm{D}}^{28}\left(c 0.1, \mathrm{CH}_{3} \mathrm{OH}\right)$ & $-7.0^{\circ}$ \\
\hline $\mathrm{UV} \lambda_{\max }^{\mathrm{CH}_{3} \mathrm{OH}} \mathrm{nm}(\varepsilon)$ & $\begin{array}{l}206(75,500), 246(14,000) \\
\quad 281(10,400)\end{array}$ \\
\hline $\operatorname{IR} v_{\max }^{\mathrm{KBr}}\left(\mathrm{cm}^{-1}\right)$ & $\begin{array}{l}3410,2927,1732,1597 \\
1462,1327,1250,1139\end{array}$ \\
\hline Melting point & $215^{\circ} \mathrm{C}$ \\
\hline \multicolumn{2}{|l|}{ Solubility } \\
\hline Soluble: & $\begin{array}{c}\mathrm{CH}_{3} \mathrm{OH}, \mathrm{CHCl}_{3}, \mathrm{CH}_{3} \mathrm{CN}, \\
\text { Acetone, } \mathrm{C}_{2} \mathrm{H}_{5} \mathrm{OH}, \\
\text { Ethyl acetate, DMSO }\end{array}$ \\
\hline Insoluble: & $\mathrm{H}_{2} \mathrm{O}$ \\
\hline
\end{tabular}

Fig. 3. ${ }^{1} \mathrm{H}-{ }^{1} \mathrm{H}$ COSY and HMBC experiments of amidepsine E.

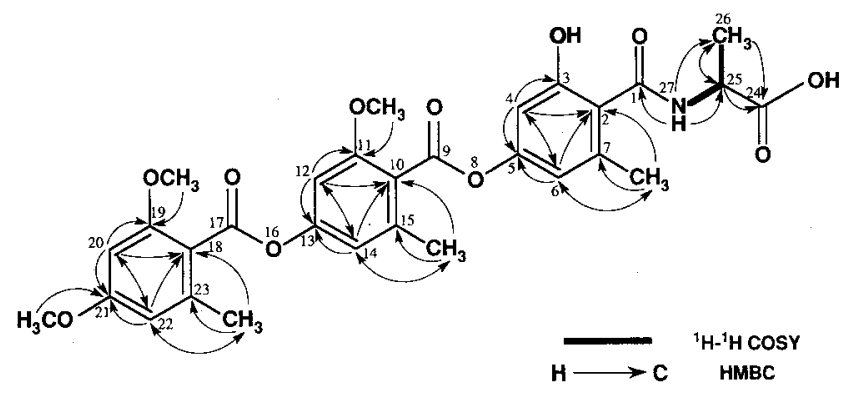

Physico-chemical properties of amidepsine $\mathrm{E}$ are summarized in Table 1 . The UV spectrum showed maxima at $206(\varepsilon 75,500), 246(\varepsilon 14,000)$ and $281 \mathrm{~nm}(\varepsilon$ 10,400 ), suggesting that amidepsine $\mathrm{E}$ has the same chromophore as amidepsine $\mathrm{A}^{21}$.

The molecular formula of amidepsine $\mathrm{E}$ was determined to be $\mathrm{C}_{30} \mathrm{H}_{31} \mathrm{O}_{11} \mathrm{~N}$ on the basis of high resolution fast atom bombardment mass spectra (HRFAB-MS) measurement $(\mathrm{m} / \mathrm{z}$, found 582.1977 , calcd 582.1975 for $\mathrm{C}_{30} \mathrm{H}_{32} \mathrm{O}_{11} \mathrm{~N}[\mathrm{M}+1]^{+}$). Comparison of the spectral data with those of amidepsine $\mathrm{A}$ indicated that from the molecular formula amidepsine $\mathrm{E}$ is larger by a $\mathrm{CH}_{2}$ unit, and that the $\mathrm{O}-\mathrm{CH}_{3}(\delta 3.87)$ proton was observed from the NMR spectra for amidepsine $E$ in place of the corresponding hydroxy residue for amidepsine $\mathrm{A}^{2)}$. In the ${ }^{1} \mathrm{H}$-detected multiple-bond heteronuclear multiple quantum coherence (HMBC) experiments the longrange couplings was observed from $\mathrm{C}-11-\mathrm{OCH}_{3}(\delta 3.87)$ to $\mathrm{C}-11(\delta 157.3)$. Thus, amidepsine $\mathrm{E}$ is suggested as 11-methoxy amidepsine $\mathrm{A}$. The structure was confirmed by ${ }^{1} \mathrm{H}^{-1} \mathrm{H}$ COSY and the $\mathrm{HMBC}$ experiments as shown in Fig. 3. Furthermore, the fragment ion peaks
Fig. 4. FAB-MS analysis of amidepsine E.

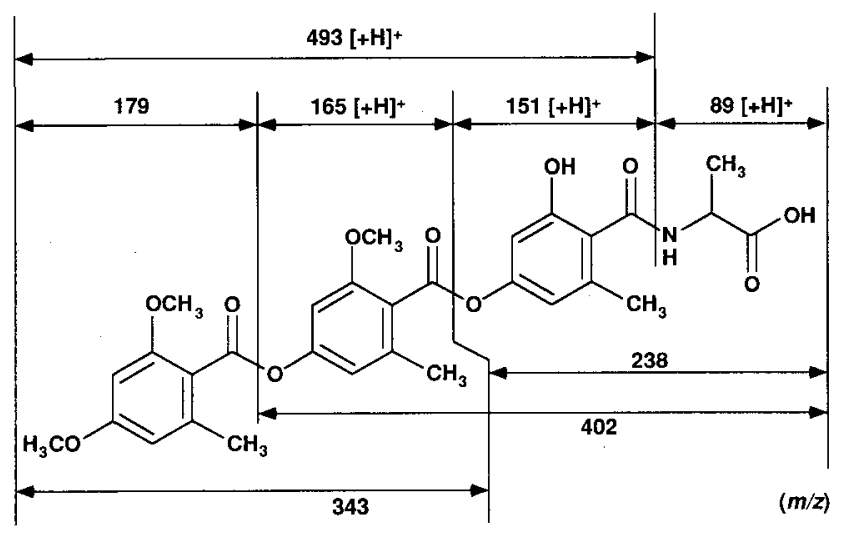

Table 2. ${ }^{1} \mathrm{H}$ and ${ }^{13} \mathrm{C}$ NMR chemical shifts of amidepsine $\mathrm{E}$.

\begin{tabular}{|c|c|c|}
\hline $\begin{array}{l}\text { Carbon } \\
\text { No. }\end{array}$ & $\begin{array}{l}{ }^{13} \mathrm{C} \text { chemical } \\
\text { shifts }(\mathrm{ppm})^{\mathrm{a}}\end{array}$ & $\begin{array}{l}{ }^{1} \mathrm{H} \text { chemical } \\
\text { shifts }(\mathrm{ppm})^{\mathrm{b}}\end{array}$ \\
\hline $\mathrm{C}-1$ & 166.5 & \\
\hline $\mathrm{C}-2$ & 123.7 & \\
\hline $\mathrm{C}-3$ & 155.2 & \\
\hline $\mathrm{C}-3-\mathrm{OH}$ & & $N^{c}$ \\
\hline C-4 & 106.4 & $6.53(\mathrm{lH}, \mathrm{d}, J=2.2 \mathrm{~Hz})$ \\
\hline $\mathrm{C}-5$ & 150.4 & \\
\hline $\mathrm{C}-6$ & 113.2 & $6.52(1 \mathrm{H}, \mathrm{d}, J=2.2 \mathrm{~Hz})$ \\
\hline C-7 & 137.6 & \\
\hline $\mathrm{C}-7-\mathrm{CH}_{3}$ & 18.9 & $2.24(3 \mathrm{H}, \mathrm{s})$ \\
\hline C-9 & 165.6 & \\
\hline $\mathrm{C}-10$ & 120.1 & \\
\hline $\mathrm{C}-11$ & 157.3 & \\
\hline $\mathrm{C}-11-\mathrm{OCH}_{3}$ & 56.5 & $3.87(3 \mathrm{H}, \mathrm{s})$ \\
\hline C- 12 & 103.5 & $6.83(1 \mathrm{H}, \mathrm{d}, J=2.0 \mathrm{~Hz})$ \\
\hline C-13 & 152.4 & \\
\hline $\mathrm{C}-14$ & 115.5 & $6.80(1 \mathrm{H}, \mathrm{d}, J=2.0 \mathrm{~Hz})$ \\
\hline $\mathrm{C}-15$ & 137.3 & \\
\hline $\mathrm{C}-15-\mathrm{CH}_{3}$ & 18.8 & $2.37(3 \mathrm{H}, \mathrm{s})$ \\
\hline $\mathrm{C}-17$ & 165.4 & \\
\hline $\mathrm{C}-18$ & 114.3 & \\
\hline C-19 & 161.7 & \\
\hline $\mathrm{C}-19-\mathrm{OCH}_{3}$ & 55.4 & $3.80(3 \mathrm{H}, \mathrm{s})$ \\
\hline $\mathrm{C}-20$ & 96.3 & $6.54(\mathrm{lH}, \mathrm{d}, J=2.2 \mathrm{~Hz})$ \\
\hline $\mathrm{C}-21$ & 158.4 & \\
\hline $\mathrm{C}-21-\mathrm{OCH}_{3}$ & 56.1 & $3.84(3 \mathrm{H}, \mathrm{s})$ \\
\hline $\mathrm{C}-22$ & 107.2 & $6.51(1 \mathrm{H}, \mathrm{d}, J=2.2 \mathrm{~Hz})$ \\
\hline $\mathrm{C}-23$ & 138.2 & \\
\hline $\mathrm{C}-23-\mathrm{CH}_{3}$ & 19.6 & $2.35(3 \mathrm{H}, \mathrm{s})$ \\
\hline C.-24 & 174.0 & \\
\hline $\mathrm{C}-24-\mathrm{OH}$ & & $\mathrm{ND}^{\mathrm{c}}$ \\
\hline $\mathrm{C}-25$ & 47.9 & $4.31(1 \mathrm{H}, \mathrm{dq}, J=7.0,7.0 \mathrm{~Hz})$ \\
\hline $\mathrm{C}-26$ & 17.0 & $1.29(3 \mathrm{H}, \mathrm{d}, J=7.0 \mathrm{~Hz})$ \\
\hline 27-NH & & $8.45(1 \mathrm{H}, \mathrm{d}, J=7.0 \mathrm{~Hz})$ \\
\hline
\end{tabular}

a Chemical shifts are shown with reference to DMSO- $d_{6}$ as $39.5 \mathrm{ppm}$.

b Chemical shifts are shown with reference to DMSO- $d_{6}$ as $2.48 \mathrm{ppm}$.

- ND; not detected.

(Fig. 4) observed in FAB-MS spectrum supported the structure. Taken together, the structure of amidepsine E was elucidated as 2-hydroxy-4-[[2-methoxy-4-[(2,4- 
Fig. 5. DGAT inhibition by amidepsine $\mathrm{E}$ in rat liver microsomes.

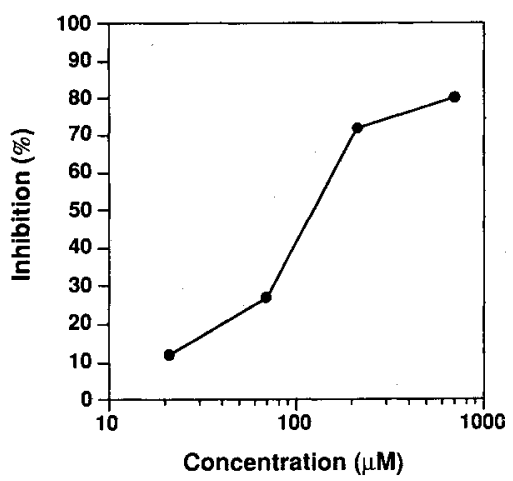

dimethoxy-6-methylbenzoyl)oxy]6-methylbenzoyl]oxy]-6-methylbenzoic acid $N$-alanine amide (Fig. 1).

Amidepsine E inhibited DGAT activity dose-dependently in the enzyme assay using rat liver microsomes ${ }^{1)}$ (Fig. 5). Amidepsine $\mathrm{E}$ was found to be a very weak DGAT inhibitor with an $\mathrm{IC}_{50}$ value of $124 \mu \mathrm{M}$ in comparison with amidepsine $\mathrm{A}$ with an $\mathrm{IC}_{50}$ value of 10.2 $\mu \mathrm{M}^{1}$ ). This indicates that the free hydroxy group at the C- 11 position is responsible for eliciting potent DGAT inhibition. To investigate the specificity for DGAT inhibition, effects of amidepsine $\mathrm{E}$ was studied on triacylglycerol (TG), phosphatidylcholine (PC) and phosphatidylethanolamine (PE) syntheses in intact Raji cells $^{1)}$ (Fig. 6). Amidepsine E showed no cytotoxic effect on Raji cells with the drug concentrations used. TG synthesis was inhibited dose-dependently with $\mathrm{IC}_{50}$ values of $91 \mu \mathrm{M}$ for amidepsine $\mathrm{E}$. However, the drug also inhibited both PC and PE syntheses to analogous extents, suggesting that it is not specific for DGAT inhibition.

Antimicrobial activity was tested using paper disks. No antimicrobial activity was observed at a concentration of $1 \mathrm{mg} / \mathrm{ml}(10 \mu \mathrm{g} /$ paper disk) for amidepsine $\mathrm{E}$ against the following microorganisms; Bacillus subtilis, Mycobacterium smegmatis, Pseudomonas aeruginosa, Escherichia coli, Micrococcus luteus, Staphylococcus aureus, Candida albicans, Saccharomyces sake, Pyricularia oryzae, Mucor racemosus and Aspergillus niger.
Fig. 6. Effects of amidepsine $\mathrm{E}$ on triacylglycerol (TG; - - ) , phosphatidylethanolamine (PE; - $\mathrm{O}-$ ) and phosphatidylcholine (PC; - - ) syntheses in Raji cells.

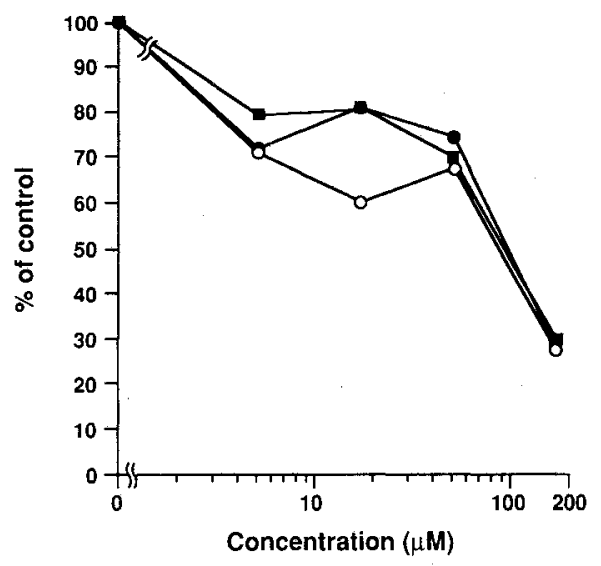

Acknowledgments

We express our thanks to Ms. N. SATO, School of Pharmaceutical Sciences, Kitasato University, for NMR spectra. This work was supported in part by grants from the Ministry of Education, Science and Culture of Japan and from Japan Keirin Association.

\section{References}

1) Tomoda, H.; M. Ito, N. Tabata, R. Masuma, Y. Yamaguchi \& S. Ōmura: Amidepsines, inhibitors of diacylglycerol acyltransferase produced by Humicola sp. I. Production, isolation and biological properties. J. Antibiotics 48: 937 941, 1995

2) Tomoda, H.; N. TABata, M. Ito \& S. Ōmura: Amidepsines, inhibitors of diacylglycerol acyltransferase produced by Humicola sp. FO-2942. II. Structure elucidation of amidepsines A, B and C. J. Antibiotics 48: $942 \sim 947,1995$

3) Bell, R. M.\& R. A. Coleman: Enzymes of triacylglycerol formation in mammals. The Enzymes 16: 87 111, 1983

4) Barron, G. L. (Ed.): Humicola traaen. In The Genera of Hyphomycetes from Soil. pp. $207 \sim 208$, Williams \& Wilkins Co., 1968

5) Fresenius, W.; J. F. K. Huber, E. Pungor, G. A. Rechnitz, W. Simon \& TH. S. West: In Tables of spectral data for structure determination of organic compounds. 2nd English ed. C120 125, Springer-Verlag, Berlin Heidelberg, 1989 